\title{
Cathepsin D Serum Mass Concentrations in Patients with Hepatocellular Carcinoma and/or Liver Cirrhosis
}

\author{
Gaetano Leto ${ }^{1}$, Francesca Maria Tumminello', Giuseppe Pizzolanti ${ }^{1}$, Giuseppe Montalto ${ }^{2}$, Maurizio Soresi ${ }^{2}$, \\ Irene Ruggeri ${ }^{2}$ and Nicola Gebbia ${ }^{1}$ \\ 1 Servizio di Chemioterapia \\ 2 Cattedra di Medicina Interna \\ Facoltà di Medicina e Chirurgia, Università di Palermo; Policlinico "P. Giaccone”, Palermo, Italy
}

Summary: Cathepsin D serum mass concentrations were determined by enzyme immunoassay in patients with hepatocellular carcinoma $(n=51)$ and/or liver cirrhosis $(n=92)$ or benign steatosis $(n=16)$ and correlated with some biochemical and clinical properties of these diseases. Increased cathepsin $D$ serum mass concentrations $(P<0.001)$ were observed in all these groups of patients as compared to normal subjects $(n=98)$. However, patients with steatosis had serum mass concentrations of this enzyme significantly lower (mean 2-3 fold) than those measured in cancer patients $(P<0.05)$ or cirrhotic patients $(P<0.001)$. Interestingly, significantly higher cathepsin $\mathrm{D}$ serum mass concentrations (mean $+62 \%)(\mathrm{P}<0.006)$ were determined in the cirrhosis group as compared to cancer patients. No correlation between cathepsin $\mathrm{D}$ and a number of clinical and biochemical properties examined, namely, $\alpha$-foetoprotein, number of neoplastic lesions and tumour size in cancer patients or, ChildPugh grade of severity of cirrhosis and other enzymes of liver function tests in the cirrhotic group was found. The present data and those from other studies which indicate that cathepsin D may be involved in carcinogenesis suggest that this enzyme may be potentially useful as an additional biochemical marker to identify cirrhotic patients who may develop precancerous hepatic nodules.

\section{Introduction}

Cathepsin $D^{1}$ ) is a lysosomal acidic endopeptidase widely distributed in animal and human tissues (1). This enzyme has been suggested to be mainly involved, in physiological conditions, in intracellular protein catabolism (1). However, growing experimental evidence indicates that cathepsin D may also promote tumour progression, invasion and metastasis $(2,3)$. In fact several investigations have shown that this proteinase appears to facilitate, at least in vitro, oncogenic transformation (4). Moreover, it has been shown that a number of human carcinoma cell lines actively secrete a precursor form of cathepsin $\mathrm{D}$ which, following autoactivation at an acid $\mathrm{pH}$, may degrade extracellular matrix or may activate latent precursor forms of other proteolytic enzymes involved in the metastatic cascade $(2,3)$. In addition, it has been recently shown that this precursor form may be endowed with mitogenic activity, thus facilitating tumour cell proliferation $(5,6)$. Although evident proof that cathepsin D may also facilitate these pro-

\footnotetext{
1) Enzymes

Cathepsin D (EC 3.4.23.5)

Alkaline phosphatase (EC 3.1.3.1)

Alanine aminotransferase (EC 2.6.1.2)

Aspartate aminotransferase (EC 2.6.1.1)

$\gamma$-Glutamyl-transferase (EC 2.3.2.2)
}

cesses in vivo has still not been provided, a consistent bulk of clinical studies have shown that this enzyme is highly expressed, in terms of mass and/or catalytic activity concentrations, in tumour cells and tissues of a number of human neoplastic diseases as compared to their normal counterpart and that these levels may correlate, in some cases, with the malignant progression of these tumours $(7-13)$. In this context several studies have also shown increased cathepsin D catalytic activity concentrations in human liver tumours as compared to normal liver tissues (14) as well elevated plasma mass concentrations of this enzyme in patients with malignant and non-malignant liver diseases as compared to healthy subjects (15). Interestingly, recent experimental in vitro and in vivo studies $(16,17)$ have evidenced in rat hepatoma cells altered intracellular processing and increased secretion of a precursor form of cathepsin D which appears to be endowed with mitogenic activity and a significant increase of the catalytic activity concentration of this enzyme in the ascites and in plasma of rats transplanted with Yoshida AH-130 hepatoma. An important consequence related to these phenomena may be, as suggested $(14,15,18)$, that cathepsin $D$ produced in excess or unusually distributed at extracellular levels following these pathological processes, may be actively secreted into the bloodstream. Therefore, increased cathepsin D 
serum content may reflect the presence of neoplastic nodules in liver tissue or may also be related to the malignant transformation of cirrhosis, a non-neoplastic liver disease which may evolve in hepatocellular carcinoma (19). In this latter case the pattern of serum levels of this enzyme may be useful as an additional biochemical marker to identify cirrhotic patients at risk to develop hepatocellular carcinoma. This finding may have clinical relevance as, to date, no serum marker including $\alpha$-foetoprotein has been found specifically reliable for the early detection of precancerous lesions $(20,21)$. On the basis of these considerations we have assessed cathepsin D serum mass concentrations in groups of patients with hepatocellular carcinoma and/or liver cirrhosis and evaluated its potential clinical interest in non-malignant and malignant liver diseases.

\section{Materials and Methods}

\section{Patients}

This study was undertaken on a total of 159 patients with malignant and non-malignant liver diseases whose clinical features are reported in table 1 . Ninety-eight registered healthy blood donors of both sex were used as control. Diagnosis of hepatocellular carcinoma was establișhed by ultrasonography and by histological findings following ultrasound-assisted fine-needle biopsy, evidence from positive diagnostic imaging and clinical and biochemical findings as well. Liver cirrhosis was diagnosed by histological findings and on the basis of unequivocal clinical and biochemical data. The Child-Pugh classification (22) was used to evaluate the grade of severity of cirrhosis. Liver steatosis was diagnosed by histological findings. All subjects with steatosis had a positive serum test for hepatitis $C$ virus. Immunoenzymatic and biochemical assays were performed on sera, previously stored at $-80^{\circ} \mathrm{C}$, obtained from venous blood samples of patients and healthy blood donors.

Determination of cathepsin D serum mass concentrations

Cathepsin D concentrations were determined by a commercially available antibody-based immunoenzymatic kit (Ciba Corning
Diagnostics, Alameda, USA) in sera of both healthy subjects and patients and diluted 1:50 with the appropriate sample diluent included in the kit. The assay detected both precursors (procathepsin $\left.\mathrm{D}, M_{\mathrm{r}} 52000, M_{\mathrm{r}} 48000\right)$ and mature $\left(M_{\mathrm{r}} 34000\right)$ forms of cathepsin D. The standard curve was linear from 0 up to $2.0 \mathrm{nmol} / \mathrm{l}$. The minimum detectable concentration, according to the manufacturer, is $0.012 \mathrm{nmol} / \mathrm{l}$. Mean cathepsin $\mathrm{D}$ serum mass concentrations in normal subjects, +2 -fold the standard deviation value or the highest serum value of the enzyme determined in healthy subjects, were taken as cut-off limits.

\section{Determination of serum $\alpha$-foetoprotein and other biochemical tests}

$\alpha$-Foetoprotein, the most sensitive and reliable serum marker for the diagnosis of hepatocellular carcinoma (23), was determined in healthy subjects and in patients by a commercially available immunoluminometric based assay kit (Byk Sangtec, Milan, Italy). Normal range values, according to the manufacturer, were $0-8 \mathrm{kIU} / \mathrm{l}$. Additionally, serum levels of 200 and $400 \mathrm{kIU} / \mathrm{l}$ were used as cutoff values as these concentrations have been reported to be highly diagnostic for this tumour $(20,23,24)$. Furthermore, the following serum biochemical constituents were also assayed and their correlation with cathepsin $\mathrm{D}$ was assessed: alkaline phosphatase ${ }^{1}$ ), albumin, alanine aminotransferase ${ }^{1}$ ), aspartate aminotransferase ${ }^{\prime}$ ), bilirubin, $\gamma$-glutamyl-transferase ${ }^{\prime}$ ), prothrombin. These assays were done with commercially available standard kits.

\section{Statistical analysis}

Data analysis was computed by the Mann-Whitney and the Kruskall-Wallis non-parametric tests. Linear regression analysis was used to compute the relationship between cathepsin $D$ and $\alpha$ foetoprotein serum concentrations in cancer patients and patients with cirrhosis. Due to the uneven distribution of the data, the Spearman rank correlation test was used to assess the correlation between cathepsin D serum levels and Child-Pugh grade of severity of cirrhosis as well as between cathepsin $\mathrm{D}$ and the other biochemical properties examined. $P$ values $<0.05$ were taken as significant.

\section{Results}

\section{Cathepsin D serum mass concentrations}

Table 2 reports the mean \pm standard error, the median and the range of total serum cathepsin $\mathrm{D}$ content in all

Tab. 1 Patients features.

\begin{tabular}{|c|c|c|c|}
\hline & $\begin{array}{l}\text { Hepatocellular carcinoma } \\
\mathrm{n}=51\end{array}$ & $\begin{array}{l}\text { Cirrhosis } \\
\mathrm{n}=92\end{array}$ & $\begin{array}{l}\text { Steatosis } \\
\mathrm{n}=16\end{array}$ \\
\hline \multicolumn{4}{|l|}{ Age (a) } \\
\hline $\begin{array}{l}\text { Mean } \pm \text { standard error } \\
\text { Range }\end{array}$ & $\begin{array}{l}61.5 \pm 1.5 \\
49-75\end{array}$ & $\begin{array}{l}55.1 \pm 1.0 \\
40-76\end{array}$ & $\begin{array}{l}39.1 \pm 3.2 \\
23-59\end{array}$ \\
\hline \multicolumn{4}{|l|}{ Sex } \\
\hline $\begin{array}{l}\text { Male } \\
\text { Female }\end{array}$ & $\begin{array}{l}36(70.6 \%) \\
15(29.4 \%)\end{array}$ & $\begin{array}{l}61(66.3 \%) \\
31(33.7 \%)\end{array}$ & $\begin{array}{r}11(68.7 \%) \\
5(31.2 \%)\end{array}$ \\
\hline \multicolumn{4}{|l|}{ Aetiological factors } \\
\hline $\begin{array}{l}\mathrm{HCV}+\mathrm{a} \\
\mathrm{HBV}+\mathrm{b} \\
\mathrm{HCV}+\mathrm{HBV}+ \\
\text { Alcohol } \\
\text { HBV+/Alcohol } \\
\text { HCV+/HBV+/Alcohol } \\
\text { Haemochromatosis } \\
\text { Unknown }\end{array}$ & $\begin{array}{rr}38 & (74.5 \%) \\
3 & (5.9 \%) \\
1 & (1.9 \%) \\
3 & (5.9 \%) \\
1 & (1.9 \%) \\
2 & (3.9 \%) \\
2 & (3.9 \%) \\
1 & (1.9 \%)\end{array}$ & $\begin{array}{l}57(61.9 \%) \\
17(18.5 \%) \\
0(0 \%) \\
7(7.6 \%) \\
0(0 \%) \\
0(0 \%) \\
0(0 \%) \\
11(11.9 \%)\end{array}$ & $16(100 \%)$ \\
\hline
\end{tabular}

a Patients with positive serum test for hepatitis $C$ virus.

b Patients with positive serum test for hepatitis B virus. 
Tab. 2 Cathepsin D serum mass concentrations (nmol/l) in normal subjects and patients with hepatocellular carcinoma and/or liver cirrhosis or benign steatosis.

\begin{tabular}{llll}
\hline Groups & Number of patients & Median (Range) & Mean \pm standard error \\
\hline Normal subjects & 98 & $\begin{array}{l}8.7 \\
(0-49.8)\end{array}$ & $10.0 \pm 0.71$ \\
- Female & 31 & 8.5 & $10.6 \pm 1.4$ \\
- Male & 67 & 9.5 & $9.9 \pm 0.85$ \\
& & $(0-49.8)$ & \\
Hepatocellular carcinoma & 51 & 31.4 & $40.6 \pm 4.2^{\mathrm{a}, \mathrm{b}}$ \\
Liver cirrhosis & & $(3.2-123.3)$ & $65.7 \pm 3.9^{\mathrm{a} . \mathrm{b} . \mathrm{c}}$ \\
Benign steatosis & 92 & 64.3 & $(8.7-196)$ \\
\end{tabular}

Data analysis was computed by the Mann-IVhitney and KruskallWallis non-parametric test.

the examined groups. No significant difference in the serum mass concentrations of this enzyme was observed between female and male normal subjects (tab. 2). Significantly higher cathepsin D serum mass concentrations (mean 4-6 fold) were determined either in cancer or cirrhotic patients as compared to normal subjects $(\mathrm{P}<0.001)$. Interestingly, cathepsin $\mathrm{D}$ serum mass concentrations in cirrhotic patients were significantly higher (mean $+62 \%$ ) than those measured in cancer patients $(P=0.006)$ (tab. 2). Statistically significant increased cathepsin D serum mass concentrations were also observed in subjects with steatosis as compared to normal subjects $(P<0.001)$. However, these concentrations were, in turn, significantly lower (mean $2-3$ fold) than those determined in the serum of cancer patients $(P<0.04)$ or patients from cirrhosis $(P<0.001)$ (tab. 2). No significant correlation between cathepsin $D$ serum mass concentrations and tumour size $(r=0.23$; $P=0.23)$ or number of neoplastic lesions $(r=0.19$; $P=0.23$ ) was evidenced in those patients evaluatable for these properties (tab. 3). Furthermore, no correlation between cathepsin $\mathrm{D}$ serum mass concentrations and grade of severity of cirrhosis was further evidenced $(\mathrm{r}=-0.78 ; \mathrm{P}=0.48)(\mathrm{tab} .3)$.

\section{$\alpha$-Foetoprotein serum concentrations}

$\alpha$-Foetoprotein serum concentrations were markedly elevated (mean 842 fold) in cancer patients as compared to normal subjects or patients with cirrhosis $(P<0.001)$ (tab. 4). These concentrations were also significantly increased (mean 6 fold) in patients with cirrhosis as compared to normal subjects $(P<0.01)$. However, this phenomenon occurred at a very lessened extent as compared to cancer patients (tab. 4). The serum concentrations of this protein were significantly different in patients with tumour size larger or smaller than $3 \mathrm{~cm}$ a $\mathrm{P}<0.001$ as compared to normal subjects;

b $\mathrm{P}<0.04$ as compared to benign steatosis;

c $\mathrm{P}<0.006$ as compared to hepatocellular carcinoma.

$(\mathrm{P}<0.05)$ and also significantly different in patients with single or multiple neoplastic lesions $(P<0.02)$. Furthermore, this tumour marker was significantly correlated with tumour size $(r=0.49, P=0.004)$ and the number of malignant lesions $(r=0.47, P=0.004)$ (tab. 4). Finally, a significant correlation $(r=0.112$, $P=0.004)$, was evidenced between $\alpha$-foetoprotein serum levels and grade of severity of cirrhosis (tab. 4).

Correlation between cathepsin D and biochemical properties of hepatocellular carcinoma and cirrhosis

No relationship between cathepsin $D$ and $\alpha$-foetoprotein levels was observed either in hepatocellular carcinoma $(r=-0.027, P=0.87)$ or cirrhotic patients $(r=0.19$, $P=0.065$ ) (data not shown). No further correlation with the other examined biochemical properties of cholestasis or cytolysis was evidenced (albumin: $r=0.13$; alanine aminotransferase: $r=-0.3$; aspartate aminotransferase: $r=-0.2$; alkaline phosphatase: $r=0.27$; bilirubin: $r=0.03 ; \gamma$-glutamyl-transferase: $r=0.28$; prothrombin: $r=0.103)$. $P$ values were not significant in any of the cases (data not shown).

Rate of increased cathepsin D and $a$-foetoprotein in patients with hepatocellular carcinoma or cirrhosis

Cathepsin D serum mass concentrations higher than the cut-off level of $24 \mathrm{nmol} / \mathrm{l}$ (mean serum content in normal subjects +2 standard deviations) were measured in $64.7 \%$ of cancer patients and in $88.0 \%$ of patients with cirrhosis (tab. 5). At a cut-off level of $50 \mathrm{nmol} / \mathrm{l}$ (highest serum mass concentration measured in healthy subjects) this phenomenon was observed in $37.2 \%$ of cancer patients and in $61.9 \%$ of patients with cirrhosis (tab. 5). 
Tab. 3 Cathepsin D scium mass concentrations (nmol/l) in patients with hepatocellular carcinoma and/or liver cirrhosis: distribution according to clinical findings.

\begin{tabular}{|c|c|c|c|}
\hline Groups & $\begin{array}{l}\text { Number of } \\
\text {.. evaluatable patients }{ }^{n}\end{array}$ & $\begin{array}{l}\text { Median } \\
\text { (Range) }\end{array}$ & Means \pm standard error \\
\hline \multicolumn{4}{|l|}{ Hepatocellular carcinoma } \\
\hline Tumour size $<3 \mathrm{~cm}$ & 10 & $\begin{array}{l}34.3 \\
(10-111.4)\end{array}$ & $41.9 \pm 10.7$ \\
\hline \multirow[t]{2}{*}{ Tumour size $>3 \mathrm{~cm}$} & 22 & $\begin{array}{l}50.3 \\
(3.2-123.3)\end{array}$ & $48.3 \pm 7.5$ \\
\hline & & & .1 \\
\hline \multicolumn{4}{|l|}{ No. of hepatic lesions } \\
\hline Unifocal & 15 & $\begin{array}{l}43.2 \\
(6.4-123.3)\end{array}$ & $44.7 \pm 8.4$ \\
\hline Multifocal & 24 & $\begin{array}{l}42.2 \\
(3.2-111.4)\end{array}$ & $43.5 \pm 6.2$ \\
\hline \multicolumn{4}{|l|}{ Liver cirrhosis } \\
\hline Child-Pugh grade A & 49 & $\begin{array}{l}60.4 \\
(10.3-196)\end{array}$ & $66.8 \pm 5.7$ \\
\hline Child-Pugh grade B & 26 & $\begin{array}{l}68.9 \\
(9.7-139.0)\end{array}$ & $67.6 \pm 7.0$ \\
\hline Child-Pugh grade C & 17 & $\begin{array}{l}58.6 \\
(8.7-145.5)\end{array}$ & $59.7 \pm 9.1$ \\
\hline
\end{tabular}

a Due to some missing samples, number of patients may be variable.

Data analysis was computed by Mann-Whitney, Kruskall-Wallis and Spearman rank correlation non-parametric tests. No significant difference or correlation between or among groups was evidenced.

Tab. $4 \alpha$-Foetoprotein serum concentrations (kIU/l) in normal subjects and patients with hepatocellular carcinoma and/or liver cirrhosis.

\begin{tabular}{llll}
\hline Groups & $\begin{array}{l}\text { Number of } \\
\text { evaluatable patients }\end{array}$ & $\begin{array}{l}\text { Median } \\
\text { (Range) }\end{array}$ & Means \pm standard error \\
\hline Normal subjects & 98 & $\begin{array}{l}1.9 \\
(0.8-10.1)\end{array}$ & $2.8 \pm 0.32$ \\
& & 33.3 & $2359 \pm 1811.3^{\mathrm{a}}$ \\
Hepatocellular carcinoma & 43 & $(0.6-78000)$ & $76.4 \pm 45.6$ \\
Tumour size $<3 \mathrm{~cm}$ & 10 & 9.3 & $4116 \pm 3228.7^{\mathrm{b}, \mathrm{c}}$
\end{tabular}

No. of hepatic lesions

$\begin{array}{lclc}\text { Unifocal } & 15 & \begin{array}{l}14.8 \\ (0.6-459.9)\end{array} & 55.1 \pm 30.6 \\ \text { Multifocal } & 22 & \begin{array}{l}316.4 \\ (2.4-78000)\end{array} & 4357 \pm 3519.7^{\text {d.e }} \\ \text { Liver cirrhosis } & 92 & 5.7 & 16.7 \pm 3.6^{\mathrm{f}} \\ \text { Child-Pugh grade A } & 49 & (0.6-225.9) & 14.6 \pm 3.4 \\ \text { Child-Pugh grade B } & 26 & 5.1 & 17.1 \pm 8.9 \\ \text { Child-Pugh grade C } & & (0.8-141.0) & 23.5 \pm 11.9^{8}\end{array}$

\footnotetext{
a Variability in the number of patients is due to some missing samples.

Data analysis was computed by Mann-Whitney, Kruskall-Wallis and Spearman rank correlation non-parametric tests.

a $\mathrm{P}<0.001$ as compared to normal subjects and liver cirrhosis;

b $\mathrm{P}<0.05$ as compared to tumour size $<3 \mathrm{~cm}$;

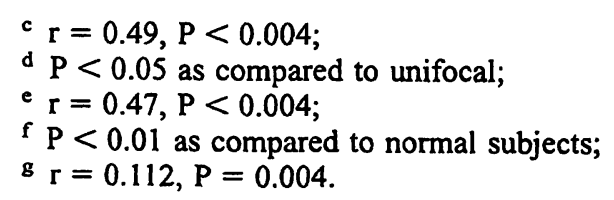


Tab. 5 Rate of increased cathepsin D and $\alpha$-foetoprotein serum concentrations in patients with hepatocellular carcinoma and/or liver cirrhosis.

\begin{tabular}{|c|c|c|c|}
\hline & $\begin{array}{l}\text { Normal } \\
\text { subjects }\end{array}$ & $\begin{array}{l}\text { Hepato- } \\
\text { cellular } \\
\text { carcinoma }\end{array}$ & $\begin{array}{l}\text { Liver } \\
\text { cirrhosis }\end{array}$ \\
\hline \multicolumn{4}{|l|}{ Cathepsin D } \\
\hline $\begin{array}{l}>24 \mathrm{nmol} / /^{\mathrm{b}} \\
>50 \mathrm{nmol} / /^{\mathrm{c}}\end{array}$ & $\begin{array}{l}3 / 98(3.1 \%) \\
0 / 98(0 \%)\end{array}$ & $\begin{array}{l}33 / 51(64.7 \%) \\
19 / 51(37.2 \%)\end{array}$ & $\begin{array}{l}89 / 92(88 \%) \\
57 / 93(61.9 \%)\end{array}$ \\
\hline \multicolumn{4}{|l|}{$\alpha$-Foetoprotein } \\
\hline $\begin{array}{l}>8 \mathrm{kIU} / /^{\mathrm{d}} \\
>200 \mathrm{klU} / \mathrm{l}^{\mathrm{e}} \\
>400 \mathrm{kIU} / \mathrm{l}^{\mathrm{e}}\end{array}$ & $\begin{array}{l}4 / 98(4.1 \%) \\
0 / 98(0 \%) \\
0 / 98(0 \%)\end{array}$ & $\begin{array}{l}34 / 49(69.4 \%) \\
16 / 49(32.6 \%) \\
12 / 49(24.5 \%)\end{array}$ & $\begin{array}{c}32 / 92(34.8 \%) \\
2 / 92 \quad(2.2 \%) \\
0 / 92(0 \%)\end{array}$ \\
\hline
\end{tabular}

a Due to some missing samples, number of evaluable subjects in this group is variable.

b Mean serum levels \pm 2 SD in normal subjects.

c Highest cathepsin D serum values determined in normal subjects.

d Upper normal serum level according to the manufacturer's instructions.

c Cut-off levels which have been reported to be diagnostic for hepatocellular carcinoma $(20,23,24)$.

Only $4 / 16(25 \%)$ or $1 / 16(6.2 \%)$ of subjects with steatosis had a cathepsin D serum mass concentration higher than 24 or $50 \mathrm{nmol} / 1$ respectively (data not shown). Further, $\alpha$-foetoprotein serum levels higher than $8 \mathrm{kIU} / \mathrm{l}$ (normal upper limit) were observed in $69.4 \%$ of patients with hepatocellular carcinoma and in $34.8 \%$ of patients with cirrhosis (tab. 5). When 200 or $400 \mathrm{kIU} / \mathrm{l}$ were selected as cut off values, $32.6 \%$ and $24.5 \%$ of these patients showed increased levels of this protein while, at a $200 \mathrm{kIU} / \mathrm{l}$ cut-off limit, this phenomenon occurred only in $2.2 \%$ of patients with cirrhosis (tab. 5).

\section{Discussion}

Total cathepsin D serum mass concentrations (i. e. proenzyme + mature form) were observed to be significantly increased in patients with hepatocellular carcinoma and/or liver cirrhosis as compared to normal subjects. Interestingly, in cirrhotic patients these concentrations were significantly higher (mean $+62 \%$ ) than those measured in cancer patients. Increased levels of this proteinase were also observed in subjects with benign steatosis, however these values were markedly $(2-3$ fold) lower than those measured in cancer patients and patients with cirrhosis. These data further confirm, in part, and extend some previous observations of Brouillet et al. (15) and Zühlsdorf et al. (25) who found evidence of elevated mass concentrations of cathepsin $D$ in the plasma or sera of patients with various liver diseases including hepatocellular carcinoma and cirrhosis. The increased serum content of cathepsin $\mathrm{D}$ observed in both cirrhotic and cancer patients may not only be the consequence of cytolytic processes which occur during the evolution of these pathological events but also related to an active secretion of this enzyme by intact hepatocytes, which contain most of the enzyme present in the human liver tissue (26). This hypothesis, supported by previous observations of Ryvnyak et al. (18) who showed that, in rats with tetrahydrocarbon chloride-induced cirrhosis, cathepsin D was largely secreted by intact heptocytes and other connective tissue cells into the intercellular space during cirrhosis, is further suggested by the present data which showed the lack of a significant correlation between cathepsin $D$ serum mass concentrations and some biochemical markers of cytolysis. As an altered secretion of this enzyme has been reported to be associated, at least in vitro, with some stages of oncogenic transformation in rat fibroblasts and with differentiation stages of some carcinoma cell lines $(4,27)$, it would be conceivable to hypothesize that the increased serum levels of this proteinase in cirrhotic patients may also be associated with carcinogenetic processes which may occur during the evolution of this disease. Moreover, a number of experimental in vitro and in vivo investigations have shown that cathepsin $D$ may induce tumour cell proliferation by acting as an autocrine mitogen $(2,5,6)$ and that intraperitoneal injections of purified preparations of cathepsin D may stimulate DNA synthesis and mitosis in intact mouse liver $(28,29)$. In addition, other studies have suggested that cathepsin D may be implicated in liver regeneration, remodelling and resorption of fibrous tissues in cirrhosis $(18,29,30)$ as well as in the activation of latent precursor forms of other proteolytic enzymes, such as cathepsin B and L, involved in the degradation of collagen in fibrotic liver and in tumour invasion and metastasis $(31,32)$. Therefore, these findings lead further to the hyopthesis that cathepsin $\mathrm{D}$ might be able to promote the malignant transformation of cirrhotic tissue. These observations may fit well with the higher cathepsin D serum mass concentrations observed in cirrhotic patients as compared to cancer patients. In conclusion, although these results indicate that cathepsin $D$ does not seem to be more reliable than $\alpha$-foetoprotein as a tool for the diagnosis of hepatocellular carcinoma, the increased serum levels of this enzyme, in addition to other proposed potential prognostic factors $(33,34)$, may be of interest as an additional biochemical marker to identify patients with cirrhosis who may develop precancerous nodules. Prospective clinical investigations to better assess this hypothesis are currently in progress.

\section{Acknowledgements}

This work was supported by grants from the Associazione Italiana per la Ricerca sul Cancro (AIRC, Milan, Italy) and Consiglio Nazionale delle Ricerche (CNR), Progetto Finalizzato ACRO, SP4 (Contract No. 95.00369.PF39). 


\section{References}

1. Barrett AJ. Cathepsin D and other carboxyl proteinases. In: Barrett AJ, editor. Protcinases in mammalian cells and tissues. Amsterdam: Elsevier/North Holland Biomed Press, 1977:209-29.

2. Rochefort $\mathrm{H}$. Biological and clinical significance of cathepsin D in breast cancer. Acta Oncol 1992; 31:125-30.

3. Leto G, Gebbia N, Rausa L, Tumminello FM. Cathepsin D in the malignant progression of neoplastic disease [review]. Anticancer Res 1992; 12:235-40.

4. Solovyeva NI, Balayevskaya TO, Dilakyan EA, Zakaldamazina-Zama TA, Podznev VF, Topol LZ, et al. Proteolytic enzymes at various stages of oncogenic transformation of rat fibroblasts. I. Aspartyl and cysteine proteinases. Int J Cancer 1995; 60:495-500.

5. Fusek $M$, Větvička $V$. Mitogenic function of procathepsin $D$ : the role of propeptide. Biochem J 1994; 303:775-80.

6. Vẽtvička V, Vẽktivičková J, Fusek M. Effects of human procathepsin $D$ on proliferation of human cell lines. Cancer Lett 1994; 79 (2):131-5.

7. Fontanini G, Bigini D, Vignati S, Ribechini A, Angeletti CA, Pingitore $R$. Immunostaining of cathepsin $D$ in non-small cell lung cancer: correlation with morphological and biological parameters. Int J Oncol 1994; 4:169-73.

8. Leto G, Tumminello FM, Russo A, Pizzolanti G, Bazan V, Gebbia N. Cathepsin D activity levels in colorectal cancer: correlation with cathepsin B and $\mathrm{L}$ and other biological and clinical parameters. Int J Oncol 1994; 5:509-15.

9. Marsigliante S, Biscozzo L, Resta L, Leo G, Mottaghi A, Maiorano $E$, et al. Immunohistochemical and immunoradiometric evaluations of total cathepsin D in human larynx. Eur $\mathbf{J}$ Cancer 1994; 30B:51-5.

10. Nazeer T, Malfetano JH, Rosano GT, Ross JS. Correlation of tumor cytosol cathepsin $\mathrm{D}$ with differentiation and invasiveness of endometrial adenocarcinoma. Am J Clin Pathol 1992; 97:764-9.

11. Podhajcer OL, Bover L, Bravo AI, Ledda F, Kariyama C, Calb $\mathrm{I}$, et al. Expression of cathepsin D in primary and metastatic human melanoma and dysplastic nevi. J Invest Dermatol 1995; 104:340-4.

12. Scambia G, Panici BP, Ferrandina G, Salerno G, D'Agostino $G$, Distefano $M$, et al. Clinical significance of cathepsin $D$ in primary ovarian cancer. Eur J Cancer 1994; 30A:935-40.

13. Zeillinger R, Swoboda H, Machacek D, Nekham D, Sliutz G, Knogler W, et al. Expression of cathepsin D in head and neck cancer. Eur J Cancer 1992; 28A (8/9):1413-5.

14. Maguchi S, Taniguchi N, Makita A. Elevated activity and increased mannose-6-phosphate in the carbohydrate moiety of cathepsin D from human hepatoma. Cancer Res 1988; 48:362-7.

15. Brouillet JP, Hanslick B, Maudelonde T, Pivat MP, Grenier J, Blanc $F$, et al. Increased plasma cathepsin $D$ concentrations in hepatic carcinoma and cirrhosis but not in breast cancer. Clin Biochem 1991; 24:491-6.

16. Isidoro $C$, Demoz M, De Stefanis D, Mainferme F, Wattiaux $\mathrm{R}$, Baccino FM. Altered intracellular processing and enhanced secretion of procathepsin $\mathrm{D}$ in a highly deviated rat hepatoma. Int J Cancer 1995; 60:61-4.

17. Isidoro $C$, Dèmoz M, Baccino FM, Bonelli G. High levels of proteolytic enzymes in the ascitic fluid and plasma of rats bearing the Yoshida AH-130 hepatoma. Invasion Metastasis 1995; 15:116-24.
18. Ryvnyak VV, Gudumak VS, Onya ES. Intracellular and extracellular cathepsin D activity in the liver during cirrhosis and involution. Bull Exp Biol Med Engl Trans 1990; 109 (2):250-3.

19. Johnson PJ, Williams K. Cirrhosis and aetiology of hepatocellular carcinoma. J Hepatol 1987; 4:140-7.

20. Colombo M, De Franchis D, Del Ninno E, Sangiovanni A, De Fazio C, Tommasini M, et al. Hepatocellular carcinoma in Italian patients with cirrhosis. New Engl J Med 1991; 325 (10):675-80.

21. Theisen ND, Fiel IM, Hytiroglou P, Schwarz M, Miller C, Thung SN. Macroregenerative nodules in cirrhosis are not associated with elevated serum or stainable tissue alpha-fetoprotein. Liver 1995; 15:30-4.

22. Pugh RNH, Murray Lyon IM, Dawson J, Pietroni MC, Williams $R$. Transection of the oesophagus for bleeding oesophageal varices. Br J Surg 1973; 60:646-9.

23. Taketa K. Alpha-fetoprotein: reevaluation in hepatology. Hepatology 1990; 12:1420-32.

24. Okuda K. Early recognition of hepatocellular carcinoma. Hepatology 1986; 6:729-38.

25. Zühldorf M, Imort M, Hasilik A, von Figura K. Molecular forms of beta-hexosaminidase and cathepsin $D$ in serum and urine of healthy subjects and patients with elevated activity of lysosomal enzymes. Biochem J 1983; 213:733-40.

26. Reid W, Valler MJ, Kay J. Immunolocalisation of cathepsin D in normal and neoplastic human tissues. J Clin Pathol 1986; 39:1323-30.

27. Huet G, Zerimech F, Dieu MC, Hemon B, Grard G, Balduyck $M$, et al. The state of differentiation of HT-29 colon carcinoma cells alters the secretion of cathepsin $D$ and of plasminogen activator. Int J Cancer 1994; 57:875-82.

28. Morioka M, Terayama H. Cathepsin D stimulates DNA-synthesis and mitosis in mouse liver in vivo. Exp Cell Res 1982; 151:273-6.

29. Terayama H, Morioka M, Koij T. Mitogenic effects of certain cathepsins and calciferin on intact liver in vivo. Int $\mathrm{J}$ Biochem 1985; 17:945-55.

30. Terayama H, Shimuzu N, Fukuzumi R. Calciferin and cathepsin D-like acid protease in serum in acute and chronic liver injuries in rats and humans. Clin Chem 1989; 35/11:2202-6.

31. Murawaki Y, Yamada S, Koda M, Hirayama C. Collagenase and collagenolytic cathepsin in normal and fibrotic rat liver. $\mathrm{J}$ Biochem 1990; 108:241-4.

32. Duffy MJ. The role of proteolytic enzymes in cancer invasion and metastasis. Clin Exp Met 1992; 10:145-55.

33. Hann H-WL, Kim CJ, London WT, Blumberg BS. Increased serum ferritin in chronic liver disease: a risk factor for primary hepatocellular carcinoma. Int J Cancer 1989; 43:376-9.

34. Tsai JF, Jeng JE, Ho MS, Chang WY, Lin ZY, Tsai JH. Clinical evaluation of serum alpha-fetoprotein and circulating immune complexes as tumor markers of hepatocellular carcinoma. $\mathrm{Br}$ J Cancer 1995; 72 (2):442-6.

\section{Received January 18/May 7, 1996}

Corresponding author: Dr. G. Leto, Section of Chemotherapy, Institute of Pharmacology, Policlinico "P. Giaccone", Via del Vespro, I-90127 Palermo, Italy 